\title{
In vivo effects of a treatment with antibodies to adipocyte plasma membranes in the rabbit
}

\author{
JP Dulor *, Y Reyne, J Nougues \\ Physiologie Animale, Unité Différenciation Cellulaire et Croissance ENSA-INRA, \\ Place Viala, 34060 Montpellier Cedex, France
}

(Received 12 June 1989; accepted 20 October 1989)

\begin{abstract}
Summary - Antibodies against rabbit adipocyte plasma membranes were injected in 6-week-old rabbits. Controls received normal IgG. Animals were killed 1,2,5 or 9 weeks after treatment. Body weight and food intake were reduced significantly until the 7 th week for the live weight and the 5 th week for the intake. Whatever the anatomical location considered, adipose tissue was markedly reduced : $-75 \%$ for week 1 and $-20 \%$ for week 9 respectively for the total adipose mass. Cell volume and enzymatic activities of $G_{3} P D H, L P L$ and LDH were highly decreased during the first 2 weeks after treatment. Simultaneously the plasma levels of triglycerides and plasma free fatty acids were increased. As shown by others in the rat, it is possible to induce a long-term fatness reduction in the rabbit by treatment with antibodies to adipocyte plasma membranes. The cytotoxic effects of antibodies have also been discussed.
\end{abstract}

adipocyte / adipose tissue metabolism / antibodie / cytotoxicity / rabbit

Résumé - Effets in vivo chez le lapin d'un immunosérum de mouton antimembranes d'adipocytes de lapin. Des anticorps dirigés contre des membranes plasmiques d'adipocytes de lapin ont été injectés à des lapins âgés de 6 semaines. Les témoins ont reçu des lgG normales. Les animaux ont été sacrifiés après 1,2, 5 ou 9 semaines. La croissance pondérale et la consommation d'aliments sont diminués significativement par le traitement. Le tissu adipeux est sévèrement affecté pendant toute la période expérimentale quelle que soit sa localisation anatomique. Les différences entre animaux traités et les témoins s'atténuent en valeur relative $(-75 \%$ à la première semaine, $-20 \%$ à la neuvième semaine). La triglycéridémie et le taux d'acides gras libres plasmatiques s'élèvent significativement au cours des premières semaines. Parallèlement, les activités enzymatiques $\left(G_{3} P D H, L P L, L D H\right)$ et la taille des adipocytes sont fortement diminuées. II est donc possible de modifier l'adiposité sur une longue période par une immunisation passive avec un antisérum dirigé contre les cellules adipeuses. L'effet cytotoxique des anticorps est discuté.

adipocyte / métabolisme du tissu adipeux / anticorps / cytotoxicité / lapin

\footnotetext{
* Correspondence and reprints
} 


\section{INTRODUCTION}

Antibodies against plasma membranes have been produced in a variety of cells including adipocytes of rat (Pillion and Czech, 1978; Futter et al, 1985; Lee et al, 1986), mouse (Thompson and Abraham, 1979; Plaas et al, 1981) and bovine origin (Cryer et al, 1984).

Antibodies against plasma membrane of rat fat cells have been shown to bind to the cell surface of isolated adipocytes and mimic some insulin actions: stimulation of glucose transport, oxidation of glucose and inhibition of catecholamine-induced lipolysis (Pillion and Czech, 1978; Pillion et al, 1979). Moreover antiadipocyte membrane serum causes cytolysis of intact adipocytes incubated in vitro (Pillion and Czech, 1978).

More recently, Flint et al (1986) confirmed these observations but, in addition, they described related cytotoxic and longterm effects of high doses of an antiserum to adipocyte plasma membranes on adipose tissue development in the rat. The cytotoxicity was complement-dependent to some extent, as cytolysis did not occur when isolated adipocytes were incubated in vitro with heated antiserum. The main effect of the treatment seemed to be a long-term reduction of the number of adipocytes in internal fat deposits. The cytotoxic effect was complement-dependent.

The importance of fat reduction in meat production is self-evident. It was therefore interesting to study this new approach in meat-producing domestic animals such as rabbit.

In the present work, antibodies against rabbit fat cell plasma membranes were raised in the sheep for further utilization. Some of these antibodies were used to study the long-term in vivo effects of a passive immunization in the rabbit.

\section{MATERIALS AND METHODS}

\section{Preparation of rabbit adipocyte plasma membranes}

Fat cells from perirenal adipose tissue of 70 day-old New Zealand rabbit were isolated according to Rodbell (1964). The cells were dissociated at $37^{\circ} \mathrm{C}$ for $1 \mathrm{~h}$ in Krebs-Ringer bicarbonate buffer $(\mathrm{pH} 7.4$ ) containing $3.5 \%$ bovine serum albumin and $1.5 \mathrm{mg} / \mathrm{ml}$ of crude collagenase (Clostridium histolyticum $0.21 \mathrm{U} / \mathrm{mg}$; Boehringer Mannheim, France).

Prior to their use for plasma membrane preparation, the isolated mature adipocytes were incubated at $37^{\circ} \mathrm{C}$ for $24 \mathrm{~h}$ with DME medium, containing $10 \%$ serum and penicillin, as described previously by Thomson and Abraham (1979) and Plaas et al (1981). According to these authors, this stage has been shown to restore the cell-surface antigens impaired by the collagenase digestion.

Plasma membranes were then prepared from these "conditioned" cells according to the method of Belsham et al (1980) using a selfforming Percoll gradient.

To assess plasma membrane recovery, 5'nucleotidase was assayed as described by Avruch and Wallach (1971) and Newby et alay (1975).

\section{Preparation of antibodies directed against adipocyte plasma membranes}

\begin{abstract}
Sheep anti-rabbit adipocyte plasma membrane serum was obtained after immunization of a merino ewe by injecting intradermally $700-800 \mu \mathrm{g}$ of plasma membrane proteins with complete Freund's adjuvant at multiple sites (Vaitukitis et al, 1971). The animals received 3 doses at 15day intervals, and blood was collected from the jugular vein 14 days after the last injection. Serum was obtained by centrifugation. A crude immunoglobulin fraction was extracted by $45 \%$ ammonium sulphate precipitation.
\end{abstract}

\section{Assessment of antibody reactivity}

The reactivity of antiserum was assessed using an indirect-labelled 2nd-antibody plasma mem- 
brane immunoassay as described by Plaas et al (1981), Cryer et al (1984), Lee (1985).

In the present work, the 2nd antibody was an immuno-purified ${ }^{125}$-labelled rabbit (anti-sheep IgG) antibody, prepared in our laboratory as described by Hales and Woodhead (1980) and Al Jafari (1985).

Binding of anti-adipocyte membrane serum to erythrocytes and fibroblasts was also examined.

\section{In vivo effects of antiserum}

Twenty-three 6-week-old New Zealand rabbits fed ad libitum were daily and intraperitoneally injected for 4 days with the equivalent of $5 \mathrm{ml}$ of antiserum as the immunoglobulin fraction.

Twenty-three control animals received a normal sheep immunoglobulin fraction under the same conditions as described for previous animals. Weight gain and food intake were monitored on a weekly basis throughout the experimental period. Groups of 5-6 animals were slaughtered at $1,2,5$ or 9 weeks after the beginning of the treatment.

At each stage, several major adipose tissue pads (dorsoscapular, axillary, inguinal, perirenal, omental) and organs (liver, kidneys, spleen) were removed and weighed. Some anatomically well-defined muscles (longissimus dorsi infra spinatus, biceps femoris, parameralis) were also removed at the 9th week.

In addition, the effect of the treatment on various metabolic parameters was studied. Blood samples were collected by intracardiac puncture. Free fatty acids (FFA) were assayed in plasma according to Dole and Meinertz (1960). Plasma triglyceride concentrations were measured enzymatically using a commercial kit (Testcombination triglyceride, Boehringer Mannheim).

Enzymatic activities were determined in the dorsoscapular and perirenal fat pads. Glycerol3-phosphate dehydrogenase (GPDH; EC 1.1.1.8) and lactate dehydrogenase (LDH; EC 1.1.1.27) were assayed spectrophotometrically as described by Wise and Green (1979) and Grimaldi et al (1978). Lipoprotein lipase (LPL; EC
3.1.1.34) was measured according to Murphy et al (1981).

Fat cell size measurements (diameter, mean volume and number of cells) were made as described previously (Reyne et al, 1985). Lipid content of fat pads was determined after lipid extraction according to Folch et al (1957). The total adipocyte number of fat deposits was calculated by dividing the total lipid weight of the deposit by the mean lipid weight of adipocytes considered as spheres. Fat cell weight was obtained by assuming that the density of adipocytes is that of triolein $(0.915 \mathrm{~g} / \mathrm{ml})$. Data were analyzed using the Mann-Whitney $U$ test.

\section{RESULTS}

\section{Antibody reactivity and specificity}

Sheep anti-rabbit adipocyte plasma membrane serum (SARS) was assessed using an indirect - labelled - second antibody immunoassay. The assay was carried out with fat cell plasma membranes $(40-50 \mu \mathrm{g}$ protein) incubated with different dilutions of SARS and $20-40000 \mathrm{cpm}$ of ${ }^{225}$ l labelledrabbit anti-sheep IgG antibodies. The titre of the antiserum was 1:10000, expressed as end-point titre, ie the dilution of antiserum which gives at least 2 -fold greater binding compared with normal serum. Optimal binding of the antiserum to fat cell plasma membranes was obtained at 500-1 000fold serum dilution.

The antiserum also bound to other cells such as erythrocytes and lung fibroblasts. But specific binding activity towards fat cell membranes remained when antisera were preincubated with lung cell cultures or packed erythrocytes (data not shown). Cell labelling with fluorescent-labelled-secondantibody indicated that antiserum bound to the cell surface of isolated mature adipocytes and cultured lung fibroblasts. 


\section{Weight gain and food intake}

Animal growth was similar for both groups before the injections with globulins. Following injection, the body weight of animals treated with antimembrane immunoglobulins was reduced markedly, compared to controls, until the 7th week after treatment (fig 1). Food intake was also lower in these animals, but for a shorter period of time: until week 5 (results not shown).

Food conversion rates ( $\mathrm{kg}$ dry matter food $/ \mathrm{kg}$ weight gain), calculated for the entire experimental period did not differ significantly for the 2 groups of animals.

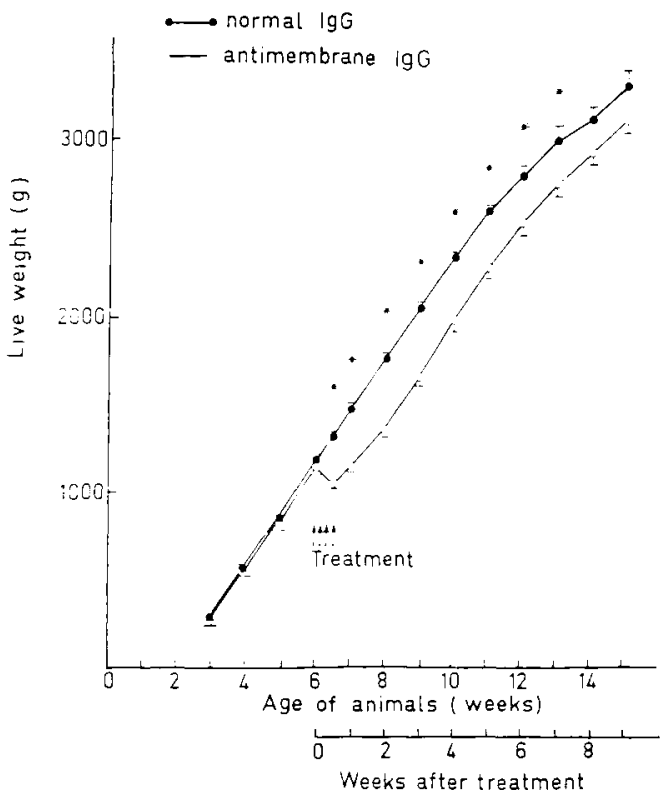

Fig 1. Pattern of weight gain in experimental rabbits before and after treatment with antibodies raised in sheep against rabbit adipocyte plasma membranes. O-O Antimembrane IgG;

Normal IgG; Mean \pm SEM. * Significant differences $(P<0.05)$ for treated animals vs controls.

\section{Tissue and organ development}

Most of the treated animals demonstrated inflammatory reactions near inguinal and axillary areas.

The total weight of the major fat pads dissected, called here "adipose mass" was significantly reduced by the antibody treatment throughout the experimental period (fig 2). The weight reduction (treated animals vs controls) was $75,52,28$ and $18 \%$ at weeks $1,2,5$ and 9 respectively. However, in absolute terms, the difference remained constant between the 2 groups of animals $(20-30 \mathrm{~g})$.

Similar results were obtained in all fat pads examined, regardless of anatomical location: ie internal fat pads, perirenal or subcutaneous fat pads, dorsoscapular (fig 2), but differences did not remain significant in the case of perirenal tissue after the second week.

An increase in spleen weight and a transient decrease in liver and kidney weights was also observed but there were no significant differences between the two groups of animals 9 weeks after treatment (table I).

Muscle development was only examined for the animals slaughtered at week 9 after treatment. As table I indicates, the total weight of the dissected muscles, which are representative of the muscle mass, was differed significantly between the 2 groups of animals. If we consider body composition ( $\%$ of empty body weight), the relative importance of muscle mass and organs was not modified by the treatment. However, the relative part of adipose tissue was markedly reduced in animals receiving antibodies (4.6 vs $5.4 \%$ ).

\section{Lipid metabolism parameters}

The level of plasma free fatty acids at week 1 and week 2 after treatment was hi- 


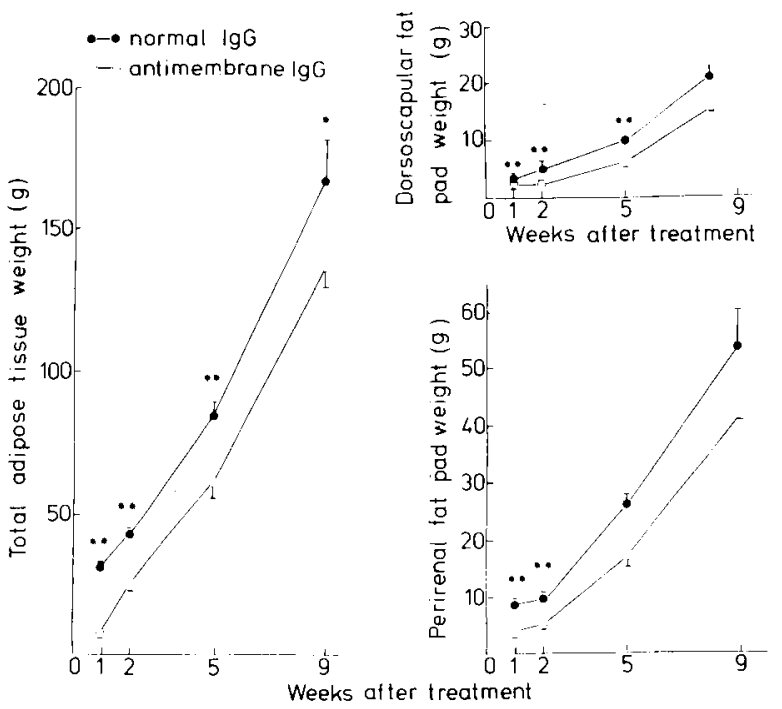

Fig 2. Changes in weights of total adipose mass, dorsoscapular and perirenal fat pads of rabbits treated with anti-adipocyte plasma membrane immunoglobins. O-OAntimembrane IgG; $\longrightarrow$ Normal lgG; Mean \pm SEM; * Significant differences $(P<0.1)$; ** Significant differences $(P<0.05)$. (The total adipose mass is considered to be the total weight of fat pads dissected: ie perirenal, omental, dorsoscapular, axillary and inguinal pads).

gher for animals injected with antibodies than for controls (table II), but at week 1 , the variability was high for animals receiving antibodies. This may be due to different individual patterns of evolution of FFA in response to the treatment. Differences were only significant $(P<0.05)$ at week 2 $(0.263 \pm 0.014 \mu \mathrm{eq} / \mathrm{ml}$ vs $0.196 \pm 0.027$ $\mu \mathrm{eq} / \mathrm{ml})$. At weeks 5 and 9 the values were the same for both groups of animals.

Table I. Tissue and organ weights, 9 weeks after treatment with antibodies against adipocyte membranes. Mean $\pm \operatorname{SEM}(N=6) ;{ }^{*} P<0.1$ treated $v s$ control.

\begin{tabular}{lcccccccc}
\hline & $\begin{array}{c}\text { Empty } \\
\text { body weight } \\
(E B W)(g)\end{array}$ & $\begin{array}{c}\text { Adipose tissue } \\
\text { mass } \\
(g) \% \text { \% }\end{array}$ & $\begin{array}{c}\text { Muscle } \\
\text { mass } \\
(g)\end{array}$ & $\begin{array}{c}\text { Kidney } \\
(g)\end{array}$ & $\begin{array}{c}\text { Liver } \\
(g)\end{array}$ & $\begin{array}{c}\text { Spleen } \\
(g)\end{array}$ \\
\hline Control animals & 3088 & 166.5 & & 165.5 & & 19.5 & 114.3 & 1.53 \\
(normal lgG) & \pm 147 & \pm 15.1 & 5.4 & \pm 5.5 & 5.3 & \pm 0.2 & \pm 6.3 & \pm 0.1 \\
Treated animals & 2922 & $137.7^{*}$ & 4.6 & $151.3^{*}$ & 5.2 & 18.9 & 107.3 & 1.50 \\
(antimembrane lgG) & \pm 91 & \pm 7.2 & & \pm 5.2 & & \pm 1.1 & \pm 5.7 & \pm 0.1 \\
\hline
\end{tabular}


Figure 3 shows that plasma triglyceride levels increased sharply in treated animals during the first 2 weeks after antiserum injections.

The levels subsequently returned to normal.

In contrast, tissue enzymatic activities of GPDH, LPL and LDH decreased markedly at weeks 1 and 2 after treatment for animals receiving antibodies, as shown in table III.

\section{Fat cell size measurements}

Cellularity studies showed a significant fall in the mean cell diameter for the experimental group at weeks 1 and 2 posttreatment, but there was no longer any difference with the controls by the end of the experimental period (fig 4). The transient decrease of this parameter, which appears in the 2 groups of animals, is unexplainable. The evolution of the weight of lipid per $\mathrm{g}$ of tissue also indicated a lower

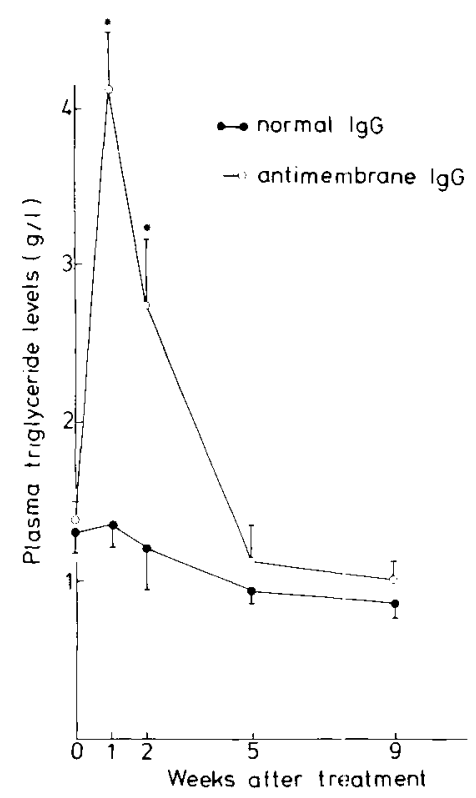

Fig 3. Changes in plasma triglyceride levels in rabbits treated with anti-adipocyte plasma membrane sheep immunoglobulins. $\mathrm{O}-\mathrm{O}$ Antimembrane IgG; $\longrightarrow$ Normal IgG; Mean \pm SEM; * Significant differences $(P<0.05)$.

Table II. Plasma free fatty acid levels in rabbits treated with anti-adipocyte plasma membrane sheep immunoglobulins (expressed as $\mu$ equivalent of palmitic acid/ml). Mean $\pm \mathrm{SEM}$; ${ }^{\star \star} P<0.05$ treated vs control animals.

\begin{tabular}{|c|c|c|c|c|c|}
\hline $\begin{array}{c}\text { Weeks } \\
\text { after treatment }\end{array}$ & 0 & 1 & 2 & 5 & 9 \\
\hline $\begin{array}{l}\text { Control animals } \\
\text { (normal IgG) } \\
(N=6)\end{array}$ & $\begin{array}{r}0.796 \\
\pm 0.275\end{array}$ & $\begin{array}{r}0.570 \\
\pm 0.060\end{array}$ & $\begin{array}{r}0.196 \\
\pm 0.027\end{array}$ & $\begin{array}{r}0.744 \\
\pm 0.103\end{array}$ & $\begin{array}{r}0.800 \\
\pm 0.050\end{array}$ \\
\hline $\begin{array}{l}\text { Treated animals } \\
\text { (antimembrane lgG) } \\
(N=6)\end{array}$ & $\begin{array}{r}0.746 \\
\pm 0.216\end{array}$ & $\begin{array}{r}0.886 \\
\pm 0.491\end{array}$ & $\begin{aligned} & 0.263^{* *} \\
\pm & 0.014\end{aligned}$ & $\begin{array}{r}0.744 \\
\pm 0.071\end{array}$ & $\begin{array}{r}0.890 \\
\pm 0.096\end{array}$ \\
\hline
\end{tabular}


Table III. Glycerol 3 phosphate dehydrogenase (GPDH), lipoproteine lipase (LPL) and lactate dehydrogenase (LDH) specific activities of perirenal fat pad (nmol- $\mathrm{mm}^{-1} \cdot \mathrm{mg}^{-1}$ protein). Mean $\pm \mathrm{SEM}$; ${ }^{\star *} P<$ 0.05 and ${ }^{*} P<0.1$ treated vs control.

\begin{tabular}{llcccc}
\hline $\begin{array}{c}\text { Weeks } \\
\text { after treatment }\end{array}$ & & 1 & 2 & 5 & 9 \\
\hline Control animals & GPDH & $922 \pm 85$ & $1279 \pm 297$ & $1758 \pm 405$ & $1876 \pm 117$ \\
(normal lgG) & LPL & $3.2 \pm 0.9$ & $3.7 \pm 1.7$ & $1.9 \pm 0.3$ & $2.4 \pm 0.7$ \\
& LDH & $5729 \pm 729$ & $7850 \pm 654$ & $13333 \pm 2425$ & $11197 \pm 1304$ \\
& $N$ & 4 & 4 & 4 & 6 \\
Treated animals & GPDH & $286 \pm 99^{* *}$ & $1377 \pm 687$ & $1370 \pm 394$ & $637 \pm 239^{* *}$ \\
(antimembrane IgG) & LPL & $0.4 \pm 0.1^{* *}$ & $1.0 \pm 0.6^{* *}$ & $2.5 \pm 0.7$ & $1.4 \pm 0.4$ \\
& LDH & $3435 \pm 1564^{*}$ & $4775 \pm 725^{* *}$ & $7850 \pm 217^{* *}$ & $10097 \pm 791$ \\
& $N$ & 4 & 4 & 4 & 6 \\
\hline
\end{tabular}

ratio for treated animals immediately after treatment.

The total number of adipocytes was calculated for each fat deposit. This number increased for the 2 groups of animals and both tissues throughout the experimental period. The effects of the treatment on the mean cell number of fat pads were not readily apparent, especially for perirenal tissue. Nevertheless, in the case of dorsoscapular tissue this number $(X \pm S E M)$ was lower for antiserum-treated animals until the second week after treatment $\left(5.2 \times 10^{6}\right.$ $\pm 1.5 \times 10^{6}$ for treated animals vs $6.5 \times 10^{6}$ $\pm 1.7 \times 10^{6}$ for controls at week 1 and $8.5 \times$ $10^{6} \pm 3.6 \times 10^{6}$ vs $12.8 \times 10^{6} \pm 4.4 \times 10^{6}$ at week 2). Differences were not significant because there was a marked intragroup variability for the parameters (cell volume, weight of lipid/g tissue, tissue weight) which were taken into account to calculate the cell number of the fat tissues.

\section{DISCUSSION}

Previous studies with cells of murine origin have indicated that antisera with specific

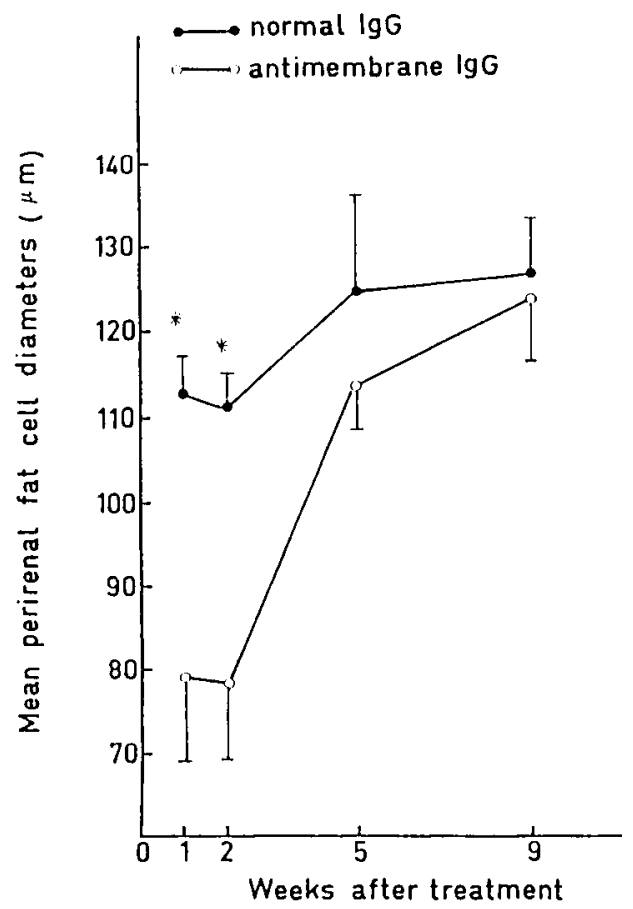

Fig 4. Changes in perirenal fat cell mean diameters in rabbits treated with anti-adipocyte plasma membrane sheep immunoglobulins. O-O Antimembrane IgG; -O Normal IgG; Mean \pm SEM; * Significant differences $(P<0.05)$. 
reactivity toward adipocytes could be produced (Thomson and Abraham, 1979; Plaas et al, 1981; Flint et al, 1986). Antibodies against adipose cell plasma membranes have been shown to induce longterm effects in rats, such as the reduction of fat cell number and thus adiposity (Flint et al, 1986).

In the present work, polyclonal antibodies have been raised in the sheep against rabbit adipocyte plasma membranes.

The in vivo treatment of growing rabbits with these antibodies resulted in a loss of live weight and a decrease of fatness which was significant until the 9th week after treatment. Leaner animals were thus obtained at 11-12 weeks of age. The nutritional efficiency did not differ between experimental and control animals when calculated throughout the experimental period.

The analysis of the variations of the weight of different organs and tissues shows clearly that adipose tissue was the major tissue affected by the treatment, although antibodies were not completely specific for the adipocytes and were not exhausted against other cell types.

The fatness reduction observed in antibody-treated animals was related to modifications in the parameters of cellularity (cell diameter, cell number) and to lipid metabolism changes.

The reduction of the adipose cell number of fat deposits reported by Flint et al (1986) in the rat was not so obvious in the rabbit. This could be partly due to the method of calculation of the cell number and to the variability of the different parameters taken into account. However, a reduction of fat cell number is noticeable for dorsoscapular adipose tissue of treated animals at the beginning of the experimental period. This was in agreement with the simul- taneous decrease of tissue protein content which is related to cell number or tissue development. The occurrence of mature adipocyte cytolysis could explain the cell number reduction and, to some extent, the counting of smaller cells.

Cytolysis was observed in vitro when isolated mature rabbit adipocytes were incubated with anti-membrane serum which was not heated to inactivate the complement (data not shown). Previous in vitro studies (Pillion and Czech, 1978; Flint et al, 1986) have also shown that such unheated antisera can cause complementmediated cytolysis of rat fat cells.

In vivo, the presence of inflammatory reactions around the axillary and inguinal lymphatic nodes suggests that lymphocyte-dependent, antibody-mediated or lymphocyte-mediated cytotoxicity could also occur as it appears in some autoimmune diseases such as Hashimoto's thyroiditis (Calder et al, 1973a, b, c).

The higher level of FFA at weeks 1 and 2 in animals receiving antibodies may be the result in cell lipolysis and could also explain the drop of cell volume. Moreover, the decrease in $\mathrm{G}_{3} \mathrm{PDH}$ activity indicates a reduction in both cellular lipogenesis and lipid accumulation. The concomitant increase of plasma triacylglycerol may be related to a fall in lipoprotein lipase activity which occurs in adipose tissue, reducing the hydrolysis of triglycerides from plasma VLDL or chylomicrons and the uptake of free fatty acids by adipose tissue. Tissue lipogenic activity $\left(\mathrm{G}_{3} \mathrm{PDH}\right)$ was restored more quickly than LPL activity.

The binding of antibodies to plasma membranes may provoke cell surface changes and so reduce the clearance of both triglycerides and FFA, increasing their plasmatic levels.

Moreover, in response to invasive stimuli and inflammatory reactions, cyto- 
kines, such as cachectin/tumor necrosis factor, are secreted by macrophages. TNF has been shown to inhibit the activity of $L P L$ at the level of its synthesis in $3 T_{3}-L_{1}$ adipocytes (Kawakami et al, 1982; Price et al, 1986) or guinea-pig fat pad (Semb et al, 1987).

According to Torti et al (1985), TNF has been also shown to suppress the biosynthesis of $\mathrm{G}_{3} \mathrm{PDH}$ mRNA in rat adipocytes. Lastly, Kawakami et al (1987) found that $3 \mathrm{~T}_{3} \mathrm{~L}_{1}$ adipocytes respond to human recombinant-TNF, inducing not only a decrease in LPL activity, but also an increase in intracellular lipolysis.

The present work shows the in vivo effects of anti-fat cell plasma membrane immunoglobulins toward adipose tissue and lipid metabolism, suggesting the role of both complement- and cell-mediated cytotoxicity.

It is possible to induce a long-term reduction of fatness in the rabbit by an in vivo treatment with antibodies against fat cell plasma membranes. However, the ability of adipose tissue to regenerate remains. The increase of cell number throughout the experimental period shows that precursor cells do not seem to be damaged.

\section{ACKNOWLEDGMENTS}

We wish to thank Mrs Thérèse Chery, Odette Frecerro, Suzanne Paolantonacci and Josette Soriano for skilled technical assistance and Marie-Claude Cavailhès for expert secretarial assistance.

\section{REFERENCES}

Al-Jafari AA (1985) Adipocytes in vitro: some aspects of their responses to hormones. PhD thesis, University of Wales
Avruch J, Wallach DFH (1971) Preparation and properties of plasma membrane and endoplasmic reticulum fragments from isolated rat fat cells. Biochim Biophys Acta 233, 334-347

Belsham GJ, Denton RM, Tanner MJA (1980) Use of a novel rapid preparation of fat-cell plasma membranes employing Percoll to investigate the effects of insulin and adrenalin on membrane protein phosphorylation within intact fat cells. Biochem J 192, 457-467

Calder EA, Penhale WJ, Barnes EW, Irvine WJ (1973a) Cytotoxic lymphocytes in Hashimoto thyroiditis. Clin Exp Immunol 14, 19-24

Calder EA, Penhale WJ, Mc Leman D, Barnes EW, Irivine WJ (1973b) Lymphocytedependent antibody-mediated cytotoxicity in Hashimoto thyroiditis. Clin Exp Immunol 14, 153-158

Calder EA, Mc Leman D, Irvine WJ (1973c) Lymphocyte cytotoxicity induced by preincubation with serum from patients with Hashimoto thyroiditis. Clin Exp Immunol 15, 467470

Cryer A, Gray BR, Woodhead JS (1984) Studies on the characterization of bovine adipocyte precursor cells and their differentiation in vitro, using an indirect-labelled-secondantibody cellular immunoassay. $J$ Dev Physiol 6, 159-176

Dole VP, Meinertz H (1960) Microdetermination of long chain fatty acids in plasma and tissues. J Biol Chem 235, 2595-2599

Flint DJ, Coggrave H, Futter CE, Gardner MJ, Clarke TJ (1986) Stimulatory and cytotoxic effects of an antiserum to adipocyte plasma membranes on adipose tissue metabolism in vitro and in vivo. Int J Obesity 10, 69-77

Folch J, Lees M, Sloane-Stanley GH (1957) A simple method for the isolation and purification of total lipids from animal tissues. $J$ Biol Chem 226, 497-509

Futter CE, Clarke TJ, Flint DJ (1985) Long-term reduction of adiposity in rats after passive immunization with an antiserum to the fat cell. In: Proc Univ. Nottingham 43rd Summer School: Control and Manipulation of Animal Growth, 7-8

Grimaldi P, Negrel R, Ailhaud G (1978) Induction of the triglyceride pathway enzymes and of lipolytic enzymes during differentiation in a preadipocyte cell line. Eur $J$ Biochem 84, 369-376 
Hales CN, Woodhead JS (1980) Labelled antibodies and their use in the immunoradiometric assay. Methods Enzymol 70, 335-355

Kawakami M, Pekala PH, Lane MD, Cerami A (1982) Lipoprotein lipase suppression in $3 T_{3}-L_{1}$ cells by an endotoxin-induced mediator from exudate cells. Proc Natl Acad $\mathrm{Sci}$ USA 79, 912-916

Kawakami $M$, Murase $T$, Ogawa $H$, Ishibashi $S$, Mori N, Takaku F, Shibata S (1987) Human recombinant TNF suppresses lipoprotein lipase activity and stimulates lipolysis in $3 T_{3}-$ $L_{1}$ cells. J Biochem 101, 331-338

Lee SR (1985) Cell surface properties of adipocytes and their precursors. PhD thesis, University of Wales

Lee SR, Tume RK, Cryer J, Cryer A (1986) Studies on the expression of adipocyte-specific cell surface antigens during the differentiation of adipocyte precursor cells in vitro. $J$ Dev Physiol 8, 207-226

Murphy MG, Negrel R, Ailhaud G (1981) Lipoprotein lipase and monoacyiglycerol lipase activities during maturation of $\mathrm{Ob} 17$ preadipocytes. Biochim Biophys Acta 664, 240-248

Newby AC, Luzio JP, Hales CN (1978) The properties and extracellular location of $5^{\prime}-$ nucleotidase of the rat fat-cell plasma membrane. Biochem J 146, 625-633

Pillion DJ, Czech MP (1978) Antibodies against intrinsic adipocyte plasma membrane proteins activate D-glucose transport independent of interaction with insulin binding sites. $J$ Biol Chem 253, 3761-3764

Pillion DJ, Grantham JR, Czech MP (1979) Biological properties of antibodies against rat adipocyte intrinsic membrane proteins. J Biol Chem 254, 3211-3220
Plaas HAK, Woodhead JS, Cryer A (1981) The use of antiserum with specific reactivity toward fat-cell surface antigen(s) to follow the progression of $3 T_{3}-L_{1}$ preadipocyte differentiation in vitro. Biosci Rep 1, 207-216

Price SR, Olivecrona T, Pekala PH (1986) Regulation of lipoprotein lipase synthesis in $3 \mathrm{~T}_{3}-\mathrm{L}_{1}$ adipocytes by cachectin. Biochem $J$ 240, 601-604

Reyne $\mathrm{Y}$, Teissier J, Nouguès J, Tebibel $\mathrm{S}$ (1985) Longitudinal study of adipose cell size in the dorso scapular and perirenal depots of the growing rabbit. $J$ Lipid Res 26, 10361046

Rodbell M (1964) Localization of lipoprotein lipase in fat cells of rat adipose tissue. $J$ Biol Chem 239, 753-755

Semb H, Peterson J, Tavernier J, Olivecrona T (1987) Multiple effects of tumour necrosis factor on lipoprotein lipase in vitro. $J$ Biol Chem 8390-8394

Thompson K, Abraham S (1979) Identification of mouse mammary adipose cells by membrane antigens. In vitro 15, 441-445

Torti FM, Dieckmann B, Beutler B, Cerami A, Ringold GM (1985) A macrophage factor inhibits adipocyte gene expression: an in vitro model of cachexia. Science 229, 867-869

Vaitukitis J, Robbins JB, Nieschlau E, Ross G (1971) Producing specific antisera with small doses of immunogen. $J$ Clin Endocrinol 33, 988-992

Wise LS, Green H (1979) Participation of one isozyme of cytosolic glycerophosphate dehydrogenase in the adipose conversion of $3 \mathrm{~T}_{3}$ cells. J Biol Chem 254, 273-275 